DOI: 10.19085/journal.sijmas030701

\title{
FEEDING KENYA 2015 AND BEYOND -WHOSE RESPONSIBILITY?
}

\author{
Dr. Rono Kiplangat Kenneth, PhD. \\ Regional Coordinator, kakamega Regional centre of Kenyatta University, Kenya.
}

(c) Scholedge International Journal of Multidisciplinary \& Allied Studies (ISSN 2394-336X), Vol.03, Issue 07 (2016) pg119-126. Published by: Scholedge R\&D Center [www.theSCHOLEDGE.org] [Email: sijmas@scholedge.org]

A NATIONAL CONFERENCE PAPER
BY. Rono Kiplangat Kenneth, PhD
Bre
This paper has been written under the Feeding Kenya 2015 and Beyond -Whose Responsibility? theme of the
National Conference as organized by Ministry of Agriculture, Livestock and Fisheries, Kenya.
Sub Theme -research, academia and extension in food nutrition security.
All views presented in the paper are those of the researcher, and do not represent the views of Ministry of
Agriculture, Livestock and Fisheries, Kenya.

\begin{abstract}
In the world, food insecurity remains an enormous challenge. Food insecurity is still a great concern for many households in Kenya. This situation is connected to high level of poverty that exists in the country, particularly in rural areas. Each year, between one to four million people receive relief food from both the national and donor agencies such as the world food program. Unfortunately policy responses have almost always inclined towards responding to emergencies of food shortages rather than on putting in place systems responsible for feeding Kenya in 2015 and beyond. This paper highlights key paradigm shift approaches to achieving food security in Kenya. The expected quick win outputs with regard to commitment to feed Kenya and methodologies on how to increase food security in Kenya have been discussed. Kenya's new constitution has devolved many responsibilities to the community level and therefore Kenya is poised to succeed in a ground up approach to boost food productivity. This is key to addressing food insecurity and feeding Kenya 2015 and beyond. This is the responsibility of national government through the ministry of Agriculture, livestock and fisheries and government through the County Agriculture docket. The arguments in this paper are informed by a number of secondary sources from which I gathered information. I have no doubt in my mind that this paper will allow the researcher to work with other global leaders in food security research to tackle one of the societal grand challenges of the $21^{\text {st }}$ century: feeding a global population of 9 -10 billion people by 2015 .
\end{abstract}

\section{Key terms:}

Food insecurity, household, poverty, rural areas, global, challenges. 


\section{INTRODUCTION}

Establishing food security is widely acknowledged as an important milestone in addressing the living standards of the rural poor. Most food insecure people live in rural areas. Food security has about 200 definitions. This paper however, makes use of the definition given in the state of food security (2010) report by the Food and Agricultural organization (FAO) which states that food security is a situation that exists when all people, at all times, have physical, social and economic access to sufficient, safe and nutritious food that meets their dietary needs and food preferences for an active and healthy life (www.sciets.org.za/scielo.php\% 3Fpid\%, 2015). Food security is a condition related to supply of food, and individuals access to it. Concerns over food security have existed throughout history. Food agricultural organization identified four pillars of food security as availability, access, utilization and stability. The state must not deprive anyone of access to adequate food. -Lack of food security goes beyond survival -the stunting of cognitive development associated with food insecurity .It causes poorer educational attainment and perpetuates poverty. In 2014, 55 out of 120 developing countries were discovered to have serious hunger situation. Hunger is a hurdle that the African continent is still grappling with.

Latin America and the Caribbean have made the greatest overall progress in increasing food security with modest progress in sub-Saharan Africa and western Asia which have been afflicted by natural disasters and conflicts. The case studies of the state of food insecurity in the world (2014) report shows that those regions such as Africa and the Latin America and the Caribbean, as well as individual countries have strengthened their political commitment to food security and nutrition. Reforestation of mangroves in xai -xai District of Mozambique restored the ecosystem and in turn increased fishery productivity and fields. Also the adoption of Zaipit technique (placing a mixture of soil and manure in small pits in (adequate lands) in Sahel led to increased soil fertility, soil fertility, decreased soil erosion and increased crop yields . Incidentally, Maize production increased from 2.4 to 3.2 million (90kg) bags between 2002 and 2010 in Kenya.

Kenya is located in East Africa and covers an area of 582,646 square Kilometres. About $80 \%$ of the country comprises Arid and Semi Arid lands (ASALS), leaving only $20 \%$ arable land which is located mainly in Eastern, western, central and south west highlands and plateaus. Kenya is divided into 47 counties. In the year 2008, Kenya's population was estimated at 40 million with a growth rate of $2.8 \%$ percent( www.knbs.or.ke./index.php retrieved on 4/5/15 at 7.32 A.m).

About half of the population is poor and is concentrated in the $20 \%$ arable land in Kenya (hdr.undp.org/en/content/kenya-nation...retrieved on 4/5/15 at 7 am ). If Kenya is to continue on a path towards middle income status, it must address challenges of food insecurity. The majority of the population in rural areas practice Agriculture, principally farming, Livestock keeping and fishing. Those in urban areas tend to be in the business and professional sectors as well as skilled and semi-skilled labour. While there are wide disparities in incidences of poverty among counties, there are also sharp disparities in poverty incidences within sub-counties in the same county.

\section{Factors contributing to food insecurity}

The majority of the severest food crises after the second half of the $20^{\text {th }}$ century were caused by a combination of several factors. The most common causes of food insecurity in Africa and other world countries were;-

- Drought and other extreme weather events

- Pests and other extreme weather events

- Climate change

- Military conflicts

- Lack of emergency plans

- Corruption and political instability

- Cash crop dependence

- AIDS

- Rapid population growth 
- Loss of farmland due to development

- Lac $k$ of resources to procure food

- Macroeconomic imbalances

- Despite overall progress, market difference across regions persists.

- Unhealthy dietary choices.

- Environmental degradation

- Gender discrimination

- Poor health and illiteracy

- A cute food security in Kenya has been exacerbated by frequent and severe shocks of agriculture.

- Pearl systems including floods impacts especially in the arid and semi arid areas.

- $\quad$ Limited land holdings.

- Natural disasters and conflicts.

- Climate change is a threat since it affects livelihoods of the most vulnerable population by increasing occurrence of natural disasters.

\section{Intervention strategies}

A stock taking of where we stand on reducing at the global level hunger shows that substantial additional effort is still needed. The amount of land in the world is finite so there is need to find ways of enabling food security to be reality. To therefore achieve the strategy of feeding the future 2015 in Kenya, several intervention strategies have been suggested in this paper. This is because, Hunger reduction requires an integrated approach, and such strategies may include;

-Applying the principle of results -based management to monitor irrigation project out come and achieve better effectiveness with quantitative and qualitative output.

-Establish core investment areas to achieve inclusive of agricultural sector growth.

-Champion achievement of "Improved nutritional status for women and children"

-Creating support mechanism at the community level aimed at improving nutrition.

- Improving access to diverse and quality food. Children should receive a minimum acceptable diet.

-Encouraging exclusive breast feeding of children under six months.

-Many people should access water.

-Integrating efforts across agricultural sector \& nutrition with attention to gender equality and poverty reduction .

-Intensify support for Priorities for nutrition services.

-Malnutrition should be detected and managed early.

-By using a community based approach through which mothers are likely to share and learn from each other's experience and interaction.

-Referral of individuals at risk for malnutrition to clinic services to allow them not only to access nutrition counseling and support as needed, but also a boarder menu of health interventions. Such referrals create an opportunity for vulnerable populations (e.g. infants from birth to 24 months) to receive essential health services that ultimately impacts their nutritional status. 
-Comprehensive surveillance mechanism to support critical information required for management of malnutrition.

-The focus should be on strengthening and integrating community based approaches that are responsible for planning and implementing food security supplementation service delivery programs.

-Emphasize the teaching of Agriculture

-Take Agriculture seriously as a business.

-Analysis of what causes food insecurity among Kenyan communities and then taking protective approaches by focusing on prevention while recognizing that there is need for addressing issues such as supplementation.

-Increasing budgetary allocation to the ministry of Agriculture, livestock and fisheries.

- Pursuing synergies which can be enhanced at low court.

-Implementing high impact intervention in order to increase the scale of agricultural productivity.

-Supporting scientific research of food importance.

-Providing leadership and specialized technical training.

-Providing agricultural policy, science technology and capacity building support to dairy/livestock and horticultural market sectors at the national level through government to government efforts.

-Providing capacity -building in the extension services/knowledge/training of water/soil management skills.

-Efforts to address the crippling problem of aflotoxin in maize so as to reduce malnutrition.

-Addressing poultry and dairy sectors by improving the quality of feed.

-Priotizing research in livestock, mycotoxins and staple foods.

-Continued financing of food for progress and schools lunch programmes.

-Adopting peace corps/Kenya new project -food security through natural resource management (FSNRM) which envisions a wider range of intervention addressing issues of food availability, access, utilization and stability. This will provide a complete package for addressing food security, nutritional environmental sustainability.

-sustainable land and water management.

-Increased food supply/ food security.

-Adoption of improved production technologies.

-Developing food program's operation for drought affected populations with the aim of protecting both lives and livelihoods.

-Asset creation activities that focus on rain water harvesting for human and livestock, island water conservation, rehabilitation of degraded agricultural land and the promotion of drought -tolerant crops e.g. sorghum and millet.

-Arid and marginal lands recovery assistance aimed at vulnerable rural communities to increase agricultural productivity and emergency assistance to respond to acute malnutrition, food insecurity and drought. 
-Valuable innovations in livestock management in, drought prone areas e.g. insurance.

-Small holder farmer targeted assistance to escape hunger and poverty.

-Building resilience to climate change.

-Increasing competitiveness and inclusiveness of targeted staple food.

-Helping significant numbers of rural populations to achieve improved income and nutritional status from strategic policy engagement and institutional investments.

-Greater diversification into higher value per hectare commodities.

-Greater focus on maize which is the driver of agricultural transformation.

-Improving links to markets.

-Enhancing input access.

-Providing affordable business development and financial services.

-Promoting greater diversification.

-Pulling rural households into income raising activities.

-Not until people feel assured of having sufficient and affordable maize -including maize products -will they feel secure food wise. The future of Kenya's food will be in diversification. Diversification out of maize and even agriculture will be highly needed.

-Expanding sources of quality and nutritious food.

- Having better post-harvest practices.

- Improved utilization of food i.e. infant and young child feeding, proper diet selection and preparation, and improved nutritional education.

- Improving transport infrastructure.

- Reducing trade barriers.

- Opening regional borders to staple food trade so as to provide cutlets for surplus production.

- Creating incentives for continued increase in productivity and reducing the risk for both producers and consumers by moderating price charges.

-Increasing the competitiveness of staple foods grown by large numbers of small holders will increase productivity and the nation's total food supply.

-Farmer incomes will increase through expanded access to markets and improved market facilities. Surplus production will decrease food prices, thereby benefiting consumers especially the rural poor who spend over 60 percent of their income on food.

- Government efforts to irrigate large tracks of land are a welcome idea in addressing food insecurity. -Sustained political commitment at the highest level is a prerequisite for hunger eradication. It entails placing of food security and nutrition at the top of political agenda and creating an enabling environment for improving food security and nutrition.

-public and private investments to raise agricultural productivity, better access to inputs, land, services, technologies and markets, measures to promote rural development, social perfection for the most vulnerable, including strengthening their reliance to conflicts and natural disasters and specific 
nutrition programmes, particularly to address macronutrient deficiency in mothers and children under five.

-Turning farming into an income generating business.

-Addressing famine

-Constructing food storage facilities

-Boosting Agricultural training centres.

-Intensifying Water pans

-Emphasising Traditional seeds

-Reaching farmers through field days.

-Linking producers to markets

-Building markets

-Improving fish productivity by increasing finger lings supplied to farmers, restore fishery stocks and habits, establish recreational marine parks and setting up several cold chain facilities and fish auction centres across Kenya.

-Vaccinating livestock against foot and mouth diseases and other trade- sensitive diseases.

-Branding livestock

-Reducing tsetse fly and trypanosomiasis density.

-Construction of medium sized abattoirs.

-Supporting farmers with milk value -addition facilities.

- Expanding irrigation,

- Reclaiming thousands of acres of land affected by erosion

-Investing massively in adequate agricultural technology

- Linking farmers to markets.

- Positioning the agricultural sector to address the challenges of food insecurity in Kenya.

-Increasing Public spending in Agriculture in Kenya.

-Reforestation.

-Food security ought to be looked at at a regional rather than national level because of regional integration, if driven by foods security concerns has a lot of potential for development in Africa.

-The failure of sectoral strategies to fight hunger calls for new approaches to rural development. Could a terrestrial approach be a suitable alternative? Terrestrial approach entails a paradigm shift in policy making in order to fight hunger.

- Strong participation in terms of effective decision making and an analysis of the food and nutrition security situation; so that national and county levels of government can respond vitally and effectively.

\section{Conclusion}

In conclusion, establishing food security is important for millions of people facing hunger in Africa and is crucial for sustainable economic diet and long term prosperity of the continent. Addressing food security in a changing climate, therefore, is a key for a rising Africa in the $21^{\text {st }}$ century. 


\section{BIBLIOGRAPHY}

Food security -Wikipedia, free encyclopedia.en.wikipedia.org/wiki/Food security retrieved on 1/5/15 at 10.50 p.m.

For mininland.fi/public/down-a. retrieved on 1/5/2015 at 6.47pm.

Global hunger index -Wikipedia, the free encyclopedia. En.wikipadia.org/ wiki/Global Hunger -retrieved on $1 / 5 / 15$ at 9.46 p.m.

hdr.undp.org/en/content/Kenya -national Human Development Report 2006. Retrieved on 4/5/15 A.m.

Siia.sipa.columbia.edu/strategic -ches - Strategic choices shaping agricultural performance and food retrieved on $1 / 5 / 15$ at 9.52 p.m.

Wabwire ,F.(2011). Long term food security in Kenya: Opportunities and challenges to implementing the US. Feed the future program. Capstone collection. paper 2420.http:digital collections.sit.edu/capstones/2420.

Website, $f$ - (2011). Long term food security in Kenya: supportive and challenges the U.S. Feed the future program “. Capstone collection. Paper 2420. Http: //digital collections.sit.edu/capstones/2420.

www.ab du.ac.uk/news/7157/ Food security groups win major funding for world leading conference. retrieved on $1 / 5 / 15$ at $11.05 \mathrm{pm}$.

www.brokeonline.eu/Articles/terrestrial retrieved on 1/5/15 at 10.43 p.m

www./eakenya.or.ke/publication / allocation retrieved on 1/5/15 at 10.22p.m.

www.fao.org/publications/sofi/2014/en/ The state of food insecurity in the world. retrieved on 1.5/2015 at 9.27 p.m.

www.fao $. o r g / f s i n / s i t e s / f s:$ The food security information network. retrieved on1/5/15 at 11.07 p.m.

www.fao.org/.../ah/894.pdf. Deriving food security statistics from national house hold budget surveys. retrieved on $1 / 5 / 15$ at 11.21 p.m.

www.fao.org/3/a -i 0430e pdf -retrieved on 1/5/15 at 11.24 p.m.

www.feedthefuture.gov/sites/default... Kenya FY 2011 -2015 multi -year strategy -Feed the future. retrieved on $1 / 5 / 2015$ at $6.55 \mathrm{p} \mathrm{m}$

www.harvest help.org.uk/causes of fro... Causes of food insecurity in Africa and other world countries retrieved on $2 / 5 / 15$ at 10.20 p.m.

www.knbs.or.ke./index.php retrieved on 4/5/15 at 7.32 A.m. hdr.undp.org/en/content/kenya-nation...accessed on $4 / 5 / 15$ at $7 \mathrm{am}$.

www.knbs.or.ke/index.php.Kenya National Bureau statistics -Kenya facts AND Figures-retrieved on 5/4/15 at 7.32 A.m.

www.MCgill.ca/.../Kari.KARI-MC Gill Food security project. Retrieved on 1/5/2015 at 8.51p.m.

www.scielo.org.za/scielo.php\% 3F PID\%.. Household food security in south Africa..retrieved on 2/5/15 at 11.09 A.M.

www.sciets.org.za/scielo.php\% 3Fpid\%, 2015). 
www.sustainabletable.org/280/food-s... -Sustainable Table/ Food security and Food Access. retrieved on 2/5/15 at 10.57 a.m.

www.thie astafrican .co.ke.Index.html .Agriculture allocation reduced, Kenya expands irrigation news. retrieved on $1 / 5 / 15$ at 10.16 p.m.

www.un.org./africarenewal/web feature .Food security; regional situations; retrieved on 1/5/15 at 10.27p.m.

\section{About the author:}

Dr. Rono Kiplangat Kenneth, PhD. is currently a regional coordinator at Kakamega Regional Centre of Kenyatta University. He holds a PhD in planning and Economics of Education.

E-mail:-kipronken@gmail.com

Phone -+254713158057

\section{According to the author:}

'The challenge of delivering food security is so great that no single discipline has the strategy to address it. That is why there is need to have a, multi - disciplinary approach, involving educational economists and knowledge exchange experts from around the world. All researchers are leaders in their fields and I'm delighted to have an opportunity to bring this expertise to bear the world's most passing challenges.' 